\title{
Humanização do Serviço: Encontros, Diálogos e Pactuações Através da Educação Permanente em Saúde
}

\author{
Leão, Luciana Melo de Souza \\ Hospital das Clínicas - Ufpe - lucianasouzaleao@yahoo.com.br
}

Introdução: a Educação Permanente em Saúde pode ser compreendida como uma ferramenta valiosa para favorecer o diálogo e a formação entre os pares no processo de trabalho e, conseqüentemente, potencializar arranjos e estratégias capazes de humanizar e melhorar a atenção ofertada nos serviços de saúde. Objetivo: Refletir sobre as possibilidades e os desafios das propostas da Educação Permanente em Saúde em um serviço especializado, oferecido por uma instituição pública de alta complexidade. Método: Análise e reflexão das ações desenvolvidas junto à equipe de profissionais, a partir da participação no curso de Educação Permanente em Saúde, oferecido pela Escola Nacional de Saúde Pública, nas modalidades à distância e presencial, no período de janeiro a setembro de 2013. Resultados: Considerando que os encontros periódicos entre os profissionais podem ser momentos estratégicos para dar unidade a uma equipe e às respectivas ações ofertadas, um grande obstáculo no respectivo serviço era a não instituição de um momento comum para que os profissionais pudessem partilhar questões operacionais e as relacionadas à formação. Porém, antes mesmo do período do curso, o grupo começou a se reunir semanalmente por cobrança e imposição da gestão da instituição. Sendo assim, havia um cenário, minimamente, possível para estabelecer trocas, conversas e pactuações a fim de humanizar o serviço prestado. por outro lado, os desafios se fizeram presentes ao nos depararmos com uma equipe bastante heterogênea que se traduzia entre os mais antigos e os mais novos na instituição; entre aqueles mais comprometidos e aqueles que carregavam suas condutas robotizadas e naturalizadas com grande resistência para qualquer mudança ou inovação; entre os que expressavam alguma preocupação com coletivo e aqueles em que as questões particulares eram a principal motivação para o respectivo comparecimento etc. ao longo do processo, a própria legitimidade dos encontros foi questionada, movimento alternado, entretanto, com momentos de maior porosidade e ressonância das ideias e propostas construídas pelo grupo, dentre as quais podemos destacar: 1) a necessidade de estruturação da sede dos encontros; 2) o agendamento e execução da pintura das salas do serviço e de sua parte externa; 3) retomada da utilização de um dos banheiros para uso dos profissionais; 4) a distribuição das salas de acordo com os horários dos atendimentos de cada colega; 5) encaminhamentos de casos entre os colegas no momento da reunião; 6) criação de uma grade de debates e discussão de casos pensados para a última reunião de cada mês etc. Considerações finais: Certamente a EPS pode ser considerada uma ferramenta possibilitadora de resignificação e humanização do modo de levar o cotidiano dos serviços ao propor mudanças calcadas na perspectiva dos espaços laborais como 'organizações vivas' e, portanto, passíveis de reajustes e revisões por parte de seus integrantes.

Leão, Luciana Melo de Souza. Humanização do Serviço: Encontros, Diálogos e Pactuações Através da Educação Permanente em Saúde. In: Anais do Congresso Internacional de Humanidades \& Humanização em Saúde [= Blucher Medical Proceedings, num.2, vol.1]. São Paulo: Editora Blucher, 2014. ISSN 2357-7282

DOI 10.5151/medpro-cihhs-10770 